\title{
CONTROL OF NODDING THISTLE
}

\author{
By E. DELAHUNTY, Department of Agriculture, Ashburton
}

\section{SUMMARY}

DURING the three seasons spring 1957 to autumn 1960 a series of trials has been laid down on pastures in the Ashburton County to find the most economical rates, materials, and times of application for the chemical control of nodding thistle (Carduus nutans). In each of the seasons there has been a heavy strike of thistle seeds in autumn, and effective control of the thistle with thistle-free plots in the following summer has been obtained by a spray application in April-May of light rates of several hormone weedkillers. Winter spraying of thistle has been unsuccessful, but September spraying has controlled the thistle on most occasions.

Nodding thistle was first recorded in New Zealand in 1899 in eastern Otago. In $1940 \mathrm{Dr}$ Allan (1) reported that it was occasionally met in scattered localities on the east coast of the South Island. Aided by a serie of dry seasons in the early $1950 \mathrm{~s}$ it rapidly spread, the patches became denser, and to-day in Ashburton County at least it can be found on threequarters of all farms and is a serious weed on half the farms.

It is a biennial with the usual two phases of a biennial: (1) seedling to low growing rosettes and (2) the rise of a main stem, production of flowers, and the setting of seed. Once seed has been set the plant dies. Normally only one main stem is produced, but should this stem be removed without killing the plant (for instance, by mowing), the plant will send up five or six stems in its place.

The control of nodding thistles has been mentioned at previous Weed Control Conferences by Duncan (1951), Symons (1956), Blomfield (1956), McLaughlin (1956), Featherstone (1957), and Fitzgerald (1957). The trials reported in this paper confirm that the thistle can be controlled by chemicals and show that, while the thistle is very readily controlled as a seedling, control at later stages is more difficult, especially if seasonal conditions are unsatisfactory.

EXPERIMENTAL

All the trials referred to in this paper were conducted on either the Lismore silt loam or the shallow phase of the same soil type. Plot size varied from season to season, but were $7 \mathrm{ft}$ or $14 \mathrm{ft}$ wide and either a $\frac{1}{2}$ or 1 chain long. All spray applications were made with a motor-powered gear pump operating at $30 \mathrm{lb}$ pressure per square inch using size 730154 teejet fan-type nozzles; the unit was hand propelled.

Spraying was normally done as near midday as possible, about 20 gallons of water per acre being applied.

All rates quoted are in pounds of acid equivalent per acre.

THE 1957 TRIALS

In autumn 1957 three trial sites were chosen, one each at Rakaia, Lismore, and Hinds. Seedling thistles were present on all three sites at time of selection, but at neither Rakaia nor Lismore did these thistles survive the next six months and consequently only the Hinds trial became more than a study of the effects of hormone weedkillers on young clover.

At Hinds the seedlings ",tablished successfully until by the summer of 1957-58 the unsprayed cormol plots had a dense cover of flowering thistles. The area on which the tria! was laid down was originally sown as a lucernecocksfoot stand, which had reverted, however, to a subterranean clovercocksfoot-hairgrass-sweet vernal sward.

On 24 May 1957 spray application on separate plots was made of 0.6 and $1.2 \mathrm{lb}$ of the potassium salt of MCPA, 0.6 and $1.2 \mathrm{lb}$ of the sodium 
salt of MCPB, 0.6 and $1.2 \mathrm{lb}$ of the amine salt of 2,4-D, and 1.0 and $1.5 \mathrm{lb}$ of the sodium salt of 2,4-DB. On the same day a broadcast application was made of the powdered sodium salt of 2,4-D at 0.6 and $1.2 \mathrm{lb}$ per acre mixed with aerial superphosphate. At the time of treatment the weather was foggy, clearing later in the day; within a week six frosts of up to 11.5 degrees had been recorded, but only 11 points of rain (on 28 May) had fallen.

No further treatments were applied until 17 September when in fine, calm conditions half the treated plots were re-treated and another set of plots were treated for the first time. There were no plots treated in spring with sodium salt of 2,4-DB nor were applications of aerial superphosphate in excess of a total of $2 \mathrm{cwt}$ per acre made to any plot. The weather after treatment remained fine and mild with light frosts until the 26th when 47 points of rain fell.

In mid summer the plots were finally inspected and the comments made were: (1) good control of seedling thistles by all treatments, (2) amine salt of 2,4-D damaged clover, (3) $0.6 \mathrm{lb}$ of potassium salt of MCPA gave good control with little clover damage, (4) sodium salt of MCPB gave a slow but complete control, (5) the mixtures of the powdered sodium salt of 2,4-D with aerial superphosphate gave patchy control with the expected response by the clovers to the fertiliser being delayed by up to three months, when compared to plots treated with aerial superphosphate alone.

With these results it was decided that a further trial should be carried out the following season.

\section{THE 1958 TRIAL}

This trial differed greatly from those of the preceding year; a lower rate of chemical was used, treatments were applied at monthly intervals, and only four chemicals were applied.

In March 1958 a site was located in the Maronan district. The paddock was a young subterranean clover-perennial ryegrass sward that was infested the previous summer with a moderate population of nodding thistle. At the time there was a dense population of seedling thistles in the two-leafed stage, with other thistles in the rosette and flowering stages. The paddock was shut up for autumn-saved grass and there was no grazing until late June; under these conditions and with a cold, dry spring there was a heavy mortality in the thistles though the unsprayed controls could be easily located.

About the 15th of each month from April until October spray application was made to separate plots of three rates $\left(\frac{1}{4}, \frac{1}{2}\right.$ and $\left.1 \mathrm{lb}\right)$ of four weedtion was made to separate plots of three rates ( $\frac{1}{4}$, $\frac{1}{2}$ and $1 \mathrm{MC}$ ) of four weedsalt of 2,4-DB, and the amine salt of 2,4-D. Due to an error in the assumed purity of the 2,4-DB that was used, the application of this material was 50 per cent greater than planned.

The results can be summarised as: (1) $1 \mathrm{lb}$ of the potassium salt of MCPA gave perfect control in all months, $\frac{1}{2} \mathrm{lb}$ was almost as good in April, May, August, and September, $\frac{1}{4} \mathrm{lb}$ was variable even in the better months and never gave a complete kill; (2) $1 \mathrm{lb}$ of the sodium salt of MCPB was effective in most applications, $\frac{1}{2} \mathrm{lb}$ gave good control, especially in spring, $\frac{1}{4} \mathrm{lb}$ was too patchy; (3) amine salt of 2,4-D at $1 \mathrm{lb}$ was good except in June-July, $\frac{1}{2} \mathrm{lb}$ was similar except that one or two thistle plants usually survived, 1 lb was unsatisfactory; (4) the sodium salt of 2,4-DB at $1 \frac{1}{2} \mathrm{lb}$ was effective in all but the mid winter months, $\frac{3}{4} \mathrm{lb}$ was similar; $\frac{1}{3} \mathrm{lb}$ plots had too many surviving thistles.

On no occasion did more than a trace of rain fall within two days of spraying. Frosts of more than 10 degrees were recorded within a day or two of all applications except those of April, June, and September.

THE 1959 TRIALS

Two trials along similar lines to that of 1958 except for the omission of all $\frac{1}{4} \mathrm{lb}$ rates and the omission of any treatment with the sodium salt of 
2,4-DB were carried out during 1959. Due to poor weather conditions the October treatments had to be delayed until late November.

Both trials were near Hinds and both were on young paddocks. On one site there were some older thistles in the rosette stage to flowering; there was a heavy strike of thistle seed in the early autumn with a resultant dense cover of small rosettes at time of initial spraying in mid April on both sites.

The weather in April was very mild; frosts were very light until late May when in one week there were five frosts of more than 10 degrees. Rain fell on 19 days in May, but apart from an occasional shower in June and early July there was little significant rain until late in July (just prior to the July spraying). Daily frosts and less than $\frac{1}{2}$ in. of rain in August was the forerunner of a cold, dry spring. The drought did not break until mid October.

The results of both trials can be summarised: (1) clover damage was less noticeable with the sodium salt of MCPB, but never severe with any treatment; (2) the application of $1 \mathrm{lb}$ of any of the three weedkillers in April or May gave perfect control; (3) the $\frac{1}{2} \mathrm{lb}$ rate was not quite as good, but still gave good control; (4) the potassium salt of MCPA was effective in all applications except in June and November; (5) the amine salt of 2,4-D was unsatisfactory except in April, May, and September; (6) the sodium salt of MCPB gave good control in April-May, moderate control in September, and was unsatisfactory in other months.

In April-May and again in August-September some 22 small-scale trials were sprayed with either the potassium salt of MCPA or the sodium salt of MCPB. These trials were scattered over the southern part of the county and were on 14 different farms. The outstanding feature of these trials was the success of April spraying-eight trials, eight successful. Patchy results occurred with spring spraying, especially with lighter rates of MCPB.

\section{DISCUSSION}

These trials were carried out to determine the cheapest and most convenient method of chemically controlling nodding thistles in pasture. What points have arisen that will enable us to make a general recommendation?

(1) Stage of growth. Seedling thistles can be readily killed by light rates of hormone weedkillers; therefore it is at this stage of growth that they should be sprayed. The objection that the thistles strike at all times of the year does not appear to be valid under the conditions of these experiments as a single application in April kept the plot weed free at least until mid summer. It is apparent that over these seasons at least the autumn strike is the major one.

(2) Stock. In all but the 1958 trial stock were grazing the paddock and the trial site at the time of spraying or within a few days of spraying. The sprayed thistles become very palatable to stock and are then readily eaten to ground level. Small thistles have insufficient root development to overcome the grazing and die. More mature plants will recover and produce the typical tight cluster of regrowth.

(3) Climatic conditions. The various hormone preparations used in these trials differed widely in their effectiveness in the colder winter months with MCPA the most effective under adverse conditions.

(4) Age and type of pasture. The weedkiller to use should be chosen according to the age and type of clover in the pasture. Because the potassium salt of MCPA was much too severe on seedling white clover, a butyric should be used under these circumstances.

(5) Cost. In Ashburton County it normally costs a farmer about 10s. per acre (plus materials) for a contractor to apply hormone weedkillers of the type mentioned in this paper. The cost of $\frac{1}{2} \mathrm{lb}$ of the potassium salt of MCPA is about $7 \mathrm{~s}$. 6d. Is $17 \mathrm{~s}$. $6 \mathrm{~d}$. per acre too much to pay for control of nodding thistles?

(6) Repeat spraying. Very little information has been obtained from these trials on the need for annual respraying of paddocks infested with nodding thistles, but it has been noticed that despite the relatively small 
plot size there has been a much larger strike of new thistles the next autumn in untreated plots than in successfully treated plots.

(7) Seasonal work. Spring spraying tends to be left until far too late, as September is a busy month on the farm with lambing and cultivation for spring crops taking precedence over weed control. April is a much quieter time of the year.

What then are our recommendations? Apply $\frac{1}{2} \mathrm{lb}$ of the potassium salt of MCPA, the sodium salt of MCPB, or the amine salt of 2,4-D to seedling thistles preferably in April or September. Use MCPB on young clover but do not apply it during cold weather. If some thistles are in the rosette stage, increase the rate nearer $1 \mathrm{lb}$ per acre. Maturer plants are normally too difficult to control with light rates of hormone weedkillers.

\section{ACKNOWLEDGMENTS}

The assistance of officers of the Farm Advisory Division, Ashburton, in laying down the trials is acknowledged.

\section{REFERENCE}

Allan, H. H. A handbook of the Naturalized Flora of New Zealand. Bulletin 83, Department of Scientific and Industrial Research, New Zealand.

\section{DISCUSSION}

Q.-In the spraying of an infestation of nodding thistle there is always a percentage not controlled. Is this due to some physiological resistance?

A.-In almost all cases you could expect a percentage that would not be killed.

Q.-Were the trial areas on old or new pastures?

A.- These trials were picked at random and contained both old and young pastures.

Q.-Regarding the point made of the palatability of thistle after spraying, would it not be an idea to spray an appetiser to encourage the stock to eat thistles?

A.-While I agree that some farmers do spray thistles with an idea of making stock eat them, I have never heard of farmers spraying an appetiser.

Q.-If nodding thistle were sprayed in flower, would this inhibit the seed?

A.-I know of only one occasion where an area sprayed at flowering stage produced thistle seed which was not viable.

Q.-Would you elaborate on damage to subterranean clover?

A.- I have not seen much damage from the light applications except where over $1 \mathrm{lb}$ was used of 2,4-D.

Q.-Do you consider that stock transferred from Canterbury to Southland carry seeds of nodding thistle?

A.-Probably stock do not carry a great amount.

Q.-Have you any information about comparative rates for control of second-year plants?

A.-No.

Comment: Normally second-year plants survive spraying if not sprayed at near to full leaf development.

Q.-Can farm management play any part in reducing infestation of nodding thistle?

A.- Subterranean clover-dominant pastures and thistles go hand in hand. No management alleviates this condition. It is not common to find serious nodding thistle problems in ryegrass dominant pastures.

Q.-Any information on volume of water per acre?

A.-Most common volume is 11 gallons per acre and most contractors consider volume is not important. 